\title{
Adenovirus detection in Guthrie cards from paediatric leukaemia cases and controls
}

\author{
GM Vasconcelos',2, M Kang', MS Pombo-de-Oliveira' ${ }^{2}$, JD Schiffman ${ }^{3}$, F Lorey ${ }^{4}$, P Buffler ${ }^{5}$ and JL Wiemels ${ }^{*, 1}$ \\ 'Laboratory for Molecular Epidemiology, Department of Epidemiology and Biostatistics, University of California, San Francisco, AC-34, I Irving Street, San \\ Francisco, CA 94143-0441, USA; ${ }^{2}$ Instituto Nacional de Câncer, Programa de Hematologia e Oncologia Pediatricás, End.:Rua André Cavalcanti, 37/5 \\ Andar-Centro, Cep: 2023 I-050-, Rio de Janeiro, Brazil; ${ }^{3}$ Department of Oncological Sciences, Huntsman Cancer Institute, University of Utah, 2000 Circle \\ of Hope (Room 4343), Salt Lake City, UT 84I I 2, USA; ${ }^{4}$ Genetic Diseases Screening Program, California Department of Public Health, 850 Marina Bay \\ Parkway, Richmond, CA 94804, USA; ${ }^{5}$ Division of Epidemiology, School of Public Health, University of California at Berkeley, 50 University Hall, MC 7360 , \\ Berkeley, CA 94720-7360, USA
}

Archived neonatal blood cards (Guthrie cards) from children who later contracted leukaemia and matched normal controls were assayed for adenovirus (AdV) C DNA content using two highly sensitive methods. In contrast to a previous report, AdV DNA was not detected at a higher frequency among neonates who later developed leukaemia, when compared with controls.

British Journal of Cancer (2008) 99, 1668- |672. doi:I0.I038/sj.bjc.66047|4 www.bjcancer.com

Published online 28 October 2008

(c) 2008 Cancer Research UK

Keywords: adenovirus; childhood leukaemia; viral aetiology; prenatal infection; Guthrie card

The causes of childhood acute lymphoblastic leukaemia (ALL), the most common type of paediatric cancer in developed countries, remain unclear. Greaves et al hypothesised that the malignant transformation of a normal cell to leukaemia requires two separate events (Greaves, 1999; Wiemels et al, 1999; Mori et al, 2002; Greaves et al, 2003). The first event would occur in utero producing a pre-leukaemic clone, and a secondary postnatal event is required for this clone to expand into full-blown disease. Either the pattern of normal childhood infections (the 'delayedinfection' hypothesis; Greaves, 1988) or specific infectious organisms (the 'population mixing' hypothesis; Kinlen, 1988) are most likely important modifiers of one or both of these events. Concerning the first event, one potential mechanism might involve a transforming response following maternal transmission of infection to the fetus. In this model, the infection in the fetus could induce a genomic instability favouring the onset of chromosomal aberrations or other mutations (Smith, 1997; Smith et al, 1997).

Molecular screening for specific candidate viruses or virus families has produced negative results (as reviewed by Greaves, 2006). Representative difference analysis (RDA) has been used to screen for anonymous, non-human sequences in the genome of common ALL (cALL) samples and no foreign sequences were detected (Mackenzie et al, 2006). In addition, degenerate PCR screens have not implicated a higher frequency of infection in leukaemia cells than in blood cells from children without leukaemia (MacKenzie et al, 2001). These data seem to provide evidence against direct viral transformation. These approaches are not infallible; however, it is possible that a very small virus or

*Correspondence: Professor JL Wiemels; E-mail: joe.wiemels@ucsf.edu Received 25 July 2008; revised 16 September 2008; accepted 17 September 2008; published online 28 October 2008 proviral component might be involved or that a transforming virus has operated through a 'hit-and-run' mechanism.

Human adenoviruses (AdVs) cause various common diseases in adults and children such as conjunctivitis, respiratory infections and diarrhoea (Wadell, 1984). Although AdV infections have never been convincingly linked to human oncogenesis, the transforming properties of human AdVs are well documented in animal models (Endter and Dobner, 2004). Nevels et al (2001) showed that AdV infections may contribute to the development of some human tumours through a mutagenesis-based hit-and-run mechanism resulting in tumours that do not carry viral genes and proteins. Other possible mechanism by which AdV could transform by a 'hit-and-run' mechanism is suggested by its stimulatory effects on DNA methyltransferase 1 (DNMT1) (Burgers et al, 2007) and the profound DNA methylation changes that occur in rodent AdV cancer models (Doerfler, 2006). Data indicating a possible role of AdVs in human oncogenesis are restricted to the investigation of serotype 5 (a $C$ class virus), and little is known about the oncogenic potential of other members of the AdV family. Recently, the first evidence for the possible contribution of $\mathrm{AdV}$ to the multistep process of tumour pathogenesis was shown in some paediatric tumour entities but not leukaemia (Kosulin et al, 2007).

A provocative recent report (Gustafsson et al, 2007) demonstrated an increased frequency of group-C AdV in Guthrie cards from children who developed ALL. This was the first description of a very high frequency of viral DNA present in Guthrie cards, and this same group found no other viral DNAs in previous Guthrie card studies (Priftakis et al, 2003; Bogdanovic et al, 2004; Isa et al, 2004; Gustafsson et al, 2006). As AdV DNA was found only in 2 out of 130 leukaemia tumour samples in one report (Kosulin et al, 2007), a hit-and-run mechanism is the only likely possibility. In this study, we sought to confirm the Guthrie card screening result in a patient population in California. 


\section{MATERIALS AND METHODS}

\section{Patients}

Guthrie cards from 89 children who later developed acute lymphocytic leukaemia and 100 healthy children were screened. Cards were obtained from a single centralized repository where they were stored dry at $-20^{\circ} \mathrm{C}$. The leukaemia cases, from which the 89 Guthrie cards were derived, were selected from a population-based case series: the Northern California Childhood leukaemia study (Chang et al, 2006). The leukaemia patients were between 1 month and 14 years of age at diagnosis; median of 4 years old. Controls were derived from the same population as the cases and matched by birthdates, gender, ethnicity and geographic region of birth; therefore, with the same age range and median age as the cases. Written informed consent was obtained from all case and control parents, and all studies were reviewed and approved by the appropriate institutional review boards.

\section{DNA extraction from Guthrie cards}

A one-eighth portion of a $1.5 \mathrm{~cm}^{2}$ card was cut and DNA was isolated with QIAamp Micro Kit (Qiagen, Hilden, Germany) according to the manufacturer's instructions. This represents approximately $150 \mathrm{ng}$ of DNA or 25000 cells. The samples were quantified using PicoGreen DNA quantification reagent (Invitrogen, Carlsbad, CA, USA).

\section{Real-time quantitative PCR}

Quantitative analysis of Guthrie card DNA was performed using real-time quantitative PCR for AdV hexon gene as described previously (Ebner et al, 2005) with slight modifications. Briefly, three different primer/probe systems were used to detect Adv species $\mathrm{A}, \mathrm{C}$ and $\mathrm{F}$ in one single reaction. Polymerase chain reactions were set up in a total volume of $20 \mu \mathrm{l}$, including $1 \times$ TaqMan Universal Master Mix (Applied Biosystems, Foster City, CA, USA), $0.2 \mu \mathrm{m}$ probes, 0.3 or $0.9 \mu \mathrm{M}$ of primers and 20 or $50 \mathrm{ng}$ of template DNA. The TaqMan probes used were labelled with 6carboxyfluorescein at the $5^{\prime}$-end and with blackhole quencher at the $3^{\prime}$-end (MWG Biotech Inc., Huntsville, AL, USA). Amplifications were carried out using the ABI Prism 7900 HT (Applied Biosystems) for a total of 50 cycles. After an initial denaturation step for $10 \mathrm{~min}$ at $95^{\circ} \mathrm{C}$, each cycle consisted of denaturation for $15 \mathrm{~s}$ at $95^{\circ} \mathrm{C}$ and annealing and primer extension for $60 \mathrm{~s}$ at $60^{\circ} \mathrm{C}$. Strict precautions were undertaken to prevent contamination of PCRs with exogenous products. To reduce the risk of false-positive results due to contamination with PCR products, dTTP was partially replaced by dUTP in the reaction master mixture and a dUTP glycosylase step was performed before each PCR. Each DNA patient sample was analysed in duplicate, standard dilutions of AdV-5 were run in quadruplicates and negative controls were included in each assay. DNA derived from AdV type 5 (AdV-5) (cat. no. 7K0013, Advanced Biotechnologies Inc., Columbia, MD, USA) served as a quantitated positive control. For the quantification of virus copies, external standard curves were established using 10-fold serial dilutions of quantified virus DNA preparations corresponding to defined virus particle equivalents. As a separate internal control, we used an Alu element-based assay, which amplifies the Intra-Yd6 sequence of human DNA (Hansen et al, 2007).

\section{Semi-nested PCR}

The AdV fiber gene (a polymorphic gene that can be used to distinguish AdV species) was screened in Guthrie card samples by using semi-nested PCR. The PCR amplifications were carried out in a final volume of $50 \mu \mathrm{l}$ consisting of $1 \times$ PCR buffer, $2.25 \mathrm{mM} \mathrm{MgCl}_{2}, 0.2 \mathrm{~mm}$ each deoxynucleosidetriphosphate (Applied
Biosystems), 2.5 U of Taq Gold polymerase (Applied Biosystems), $150 \mathrm{~nm}$ each primer (Garnett et al, 2002) and $20 \mathrm{ng}$ of template DNA. Polymerase chain reaction amplification was carried out with 1 cycle at $95^{\circ} \mathrm{C}$ for $4 \mathrm{~min}, 35$ cycles of $95^{\circ} \mathrm{C}$ for $45 \mathrm{~s}, 56^{\circ} \mathrm{C}$ for $45 \mathrm{~s}$ and $72^{\circ} \mathrm{C}$ for $45 \mathrm{~s}$, followed by 1 cycle at $72^{\circ} \mathrm{C}$ for $3 \mathrm{~min}$. Following the initial cycle of PCR, $1 \mu \mathrm{l}$ of primary PCR product was used in a second amplification. The second PCR amplification was done for 25 cycles. Polymerase chain reaction products were visualised on a $1.8 \%$ agarose gel stained with ethidium bromide. The fiber primary PCR product was $408 \mathrm{bp}$, and the semi-nested PCR product was $175 \mathrm{bp}$.

\section{RESULTS}

Eighty of the 89 cases had B-precursor ALL and a typical pattern of cytogenetic rearrangements (Table 1). Six patients had T-cell ALL, with three being indeterminate or biphenotypic (Table 1).

\section{Sensitivity of the assays}

The lower detection limit of the molecular tests described was assessed by the analysis of dilution series (ranging from 0.1 to $10^{4}$ copies) prepared using quantified viral DNA derived from the reference strain (AdV-5). Reproducible quantification of virus copies was obtained by RQ-PCR in the presence of $1-10^{4}$ particles per reaction (Figure 1). When the threshold cycle values of the standard dilutions were plotted against the $\log _{10}$ of the starting copy number, the correlation coefficient values were higher than 0.990 and the slope of the line was lower than -3.34 , indicating an amplification efficiency of $99-100 \%$. With the nested PCR, the detection limit was higher. Positive results were obtained with starting quantity as low as 0.1 viral copy (Figure 2).

\section{RQ-PCR}

DNA samples from 40 ALL patients and from 56 normal controls were analysed for the presence of AdV subgroup A, C and F DNA by real-time PCR, which is slightly less sensitive than the nested assay. The degree of homology of AdV subgroups permitted the establishment of a single RQ-PCR covering all serotypes of the species A, C and F (Ebner et al, 2005). Individual samples were assayed two times, on separate occasions. In the first set of reactions, $20 \mathrm{ng}$ of each DNA sample $(n=96)$ was run in duplicate.

Table I Characteristics of leukaemia cases whose Guthrie cards were tested for the presence of adenovirus

\begin{tabular}{lcc}
\hline Patient characteristics & N & AdV DNA \\
\hline Controls & 100 & I \\
Cases & 89 & 0 \\
$\quad$ BP ALL & 80 & \\
T ALL & 6 & \\
Unknown lineage & 3 & \\
Karyotype & & \\
Hyperdiploid (47-50) & 12 & \\
Hyperdiploid (5I-67) & 27 & \\
Triploid & 2 & \\
Pseudodiploid & 27 & \\
$\quad$ (I2;2I) & 13 & \\
chrl Iq2.3 & 8 & \\
Others & 4 & \\
No abnormality & 9 &
\end{tabular}

$\mathrm{AdV}=$ adenovirus; $\mathrm{ALL}=$ acute lymphoblastic leukaemia; $\mathrm{Bp} \mathrm{ALL}=\mathrm{B}$-cell precursor $\mathrm{ALL} ; \mathrm{T} A L L=\mathrm{T}$-cell ALL. ${ }^{\mathrm{a}} \mathrm{Among} \mathrm{Bp} \mathrm{ALL}$ only. Characteristics of $\mathrm{T}$-cell $\mathrm{ALL}$ are not shown. 

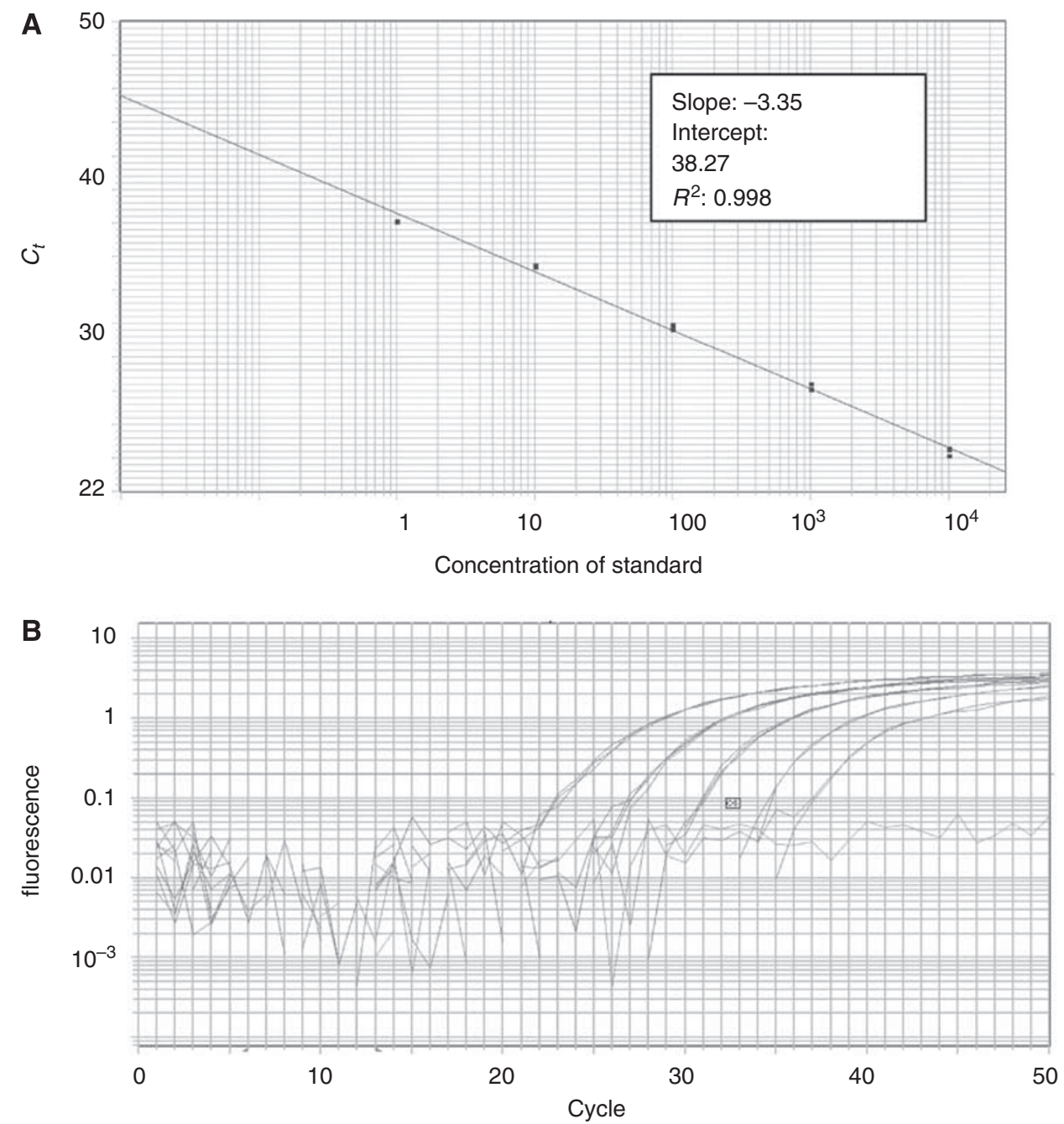

Figure I Real-time PCR standardisation of AdV ACF reaction. (A) Standard curve plot of the I0-fold serial dilution of AdV-5. Linearity is observed throughout the range from I to $10^{4}$ copies per reaction. (B) Amplification curves of the hexon gene with AdV-5 control DNA. The control DNA is a certified quantified standard.

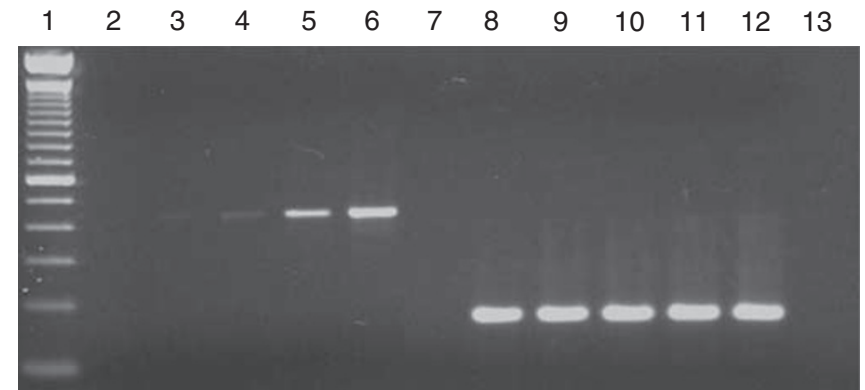

Figure 2 Detection of the fiber gene of AdV C genome by nested PCR. Serial 10 -fold dilutions of the control DNA, ranging from 0.1 copy to $10^{3}$ copies of the genome were used in the first reactions. Lane I, molecular weight marker (100 bp); lanes $2-6$, first round of amplification ( $0.1,1,10$, 100 and 1000 copies, respectively); lanes $8-12$, semi-nested amplification of the dilution series only; and lanes 7 and 13, negative controls.

Then, a second set was run, with $50 \mathrm{ng}$ of each DNA sample $(n=78)$ also in duplicate. None of the samples contained detectable AdV DNA, and all samples amplified for Yd6 control gene at a level consistent with the amount of DNA added (Hansen et al, 2007). There was no relationship between the age of the card

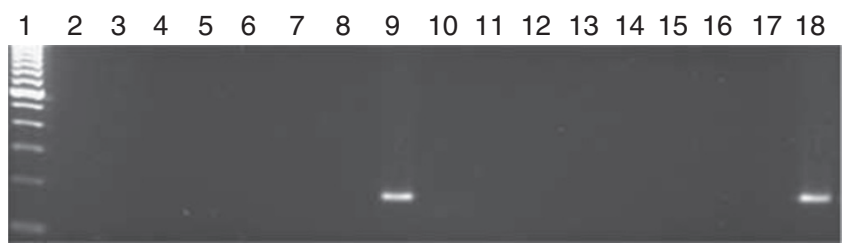

Figure 3 Detection of fiber gene of AdV-C by nested PCR in ALL samples. Results from the nested (second round) PCR are shown. Lane I, 100 bp molecular weight marker; lanes $2-8$ and $10-17$, negative samples; lane 9, positive sample; and lane 18, positive control AdV-5.

(i.e., the age of the child) and the ease of amplification of this control gene. Owing to the negative results with this method, we moved to the two-round nested PCR approach.

\section{Semi-nested PCR}

Nested PCRs were carried out with DNA samples from 89 ALL patients and from 100 normal controls for detection of the fiber gene. The primers used in these reactions were designed to amplify all serotypes of the AdV subgroup C (Garnett et al, 2002). Only one of the 189 samples contained amplifiable AdV DNA (Figure 3) and 
it belonged to a normal control subject. It is likely that this sample carries very low AdV particle number, as it did not amplify by RQ-PCR.

\section{DISCUSSION}

It has been suggested that infection in utero with a virus that has an oncogenic potential could be involved in the initiation of ALL, by inducing genomic instability in B-lymphocytes. As AdV is a common infection in intrauterine environments (Van den Veyver et al, 1998; Baschat et al, 2003), and expression of the $E 1 A$ and $E 1 B$ oncogenes of AdV-5 may transform normal cells into a tumorigenic phenotype (Nevels et al, 2001), this virus could potentially be involved in the initial event promoting leukaemia. In this study, human AdV DNA subtypes A, C or F was not detected by PCR in the blood from Guthrie cards neither in children who had developed ALL $(n=89)$ nor from healthy controls $(n=99)$, except for one normal control sample. These results demonstrate a lower rate of positivity $(\sim 0.5 \%)$ than that found for $\mathrm{AdV}$ in amniocentesis samples from the second trimester of normal pregnancies ( 5\%; Baschat et al, 2003). Exposure and infection to AdV in utero is then likely more common than would be indicated by the current results; however, it makes sense that AdV type $C$ would be less likely to be found in blood, as its natural tropism is respiratory epithelium. The virus is normally shed through stool and therefore could be deposited in amniotic fluid when a fetus is infected. All of our DNA samples contained amplifiable DNA at amounts that correlated with Pico-green assays when tested by Alu-element Yd6; therefore, PCR inhibitors do not cause our negative results from the Guthrie cards. Recently, Gustafsson et al (2007), using similar methodology (nested PCR and RQ-PCR) that we used in this study, showed a very high frequency of AdV group C-positive samples in ALL patients (27\%) when compared with controls (6\%). Unless the Swedish mothers are exposed to very different environmental and genetic factors that influence transmission of infection to a fetus and detection in blood, when compared with pregnant woman in California, there is no obvious explanation for this discrepancy. As sero- and molecular positivity to AdV $C$ are not significantly higher in Swedish compared with USA populations (Ostlund et al, 2004; Arnold et al, 2008), we do not think that there are population differences in exposure and fetal transmission; rather the results of Gustafsson may be on tha basis of laboratory issues that are difficult to evaluate given the limited data provided (Gustafsson et al, 2007). The differences between the two studies may also arise from concurrent exposures that might increase infectivity of the virus in Sweden including smoking habits or respiratory diseases. Our results, presented here with positive and negative controls and

\section{REFERENCES}

Arnold JC, Singh KK, Spector SA, Sawyer MH (2008) Undiagnosed respiratory viruses in children. Pediatrics 121: 631-637

Baschat AA, Towbin J, Bowles NE, Harman CR, Weiner CP (2003) Prevalence of viral DNA in amniotic fluid of low-risk pregnancies in the second trimester. J Matern Fetal Neonatal Med 13: 381-384

Bogdanovic G, Jernberg AG, Priftakis P, Grillner L, Gustafsson B (2004) Human herpes virus 6 or Epstein-Barr virus were not detected in Guthrie cards from children who later developed leukaemia. Br J Cancer 91: 913-915

Burgers WA, Blanchon L, Pradhan S, de Launoit Y, Kouzarides T, Fuks F (2007) Viral oncoproteins target the DNA methyltransferases. Oncogene 26: $1650-1655$

Chang JS, Selvin S, Metayer C, Crouse V, Golembesky A, Buffler PA (2006) Parental smoking and the risk of childhood leukemia. Am J Epidemiol 163: $1091-1100$

Doerfler W (2006) De novo methylation, long-term promoter silencing, methylation patterns in the human genome, and consequences of foreign DNA insertion. Curr Top Microbiol Immunol 301: 125-175 a certified DNA standard, are defensible as negative, and we do not encourage further research into the detection of AdV in Guthrie cards for the purposes of studying leukaemia aetiology, at least in California.

Speculations concerning a link between infections and childhood leukaemia have been published for decades and, despite a multitude of epidemiological correlations, a definitive mechanistic explanation remains elusive. The absence of any viral DNA in Guthrie cards does not constitute negative evidence of the role of infections in leukaemia aetiology if the critical exposure is postnatal. The early postnatal period is the time period with the strongest epidemiological evidence concerning a link between infectious disease history and childhood leukaemia (Greaves, 2006). The absence of AdV DNA in Guthrie cards does not rule out a hit-and-run mechanism of this virus; its lack of detection in Guthrie cards in this study argues only against a role of this virus in prenatal infection. Future studies may examine the role of AdV and other specific viruses in the mother's and child's life. To date, however, strong evidence for specific viral involvement in childhood leukemogenesis is quite limited, compared with the large body of strong evidence linking immune modulation through unspecified common childhood infections as a protective factor.

\section{ACKNOWLEDGEMENTS}

We thank the families who participated in the NCCLS and the clinical collaborators from University of California Davis Medical Center (Dr Jonathan Ducore), University of California San Francisco (Drs Mignon Loh and Katherine Matthay), Children's Hospital of Central California (Dr Vonda Crouse), Lucile Packard Children's Hospital (Dr Gary Dahl), Children's Hospital Oakland (Dr James Feusner), Kaiser Permanente Sacramento (Dr Vincent Kiley), Kaiser Permanente Santa Clara (Drs Carolyn Russo and Alan Wong), Kaiser Permanente San Francisco (Dr Kenneth Leung) and Kaiser Permanente Oakland (Dr Stacy Month). We also thank Catherine Camacho of the Center for Family Health, California Department of Public Health (CDPH) for access to Guthrie cards, and Martin Kharrazi and the staff of the Genetic Disease Laboratory and others in the Genetic Disease Screening Program (CDPH) for providing well-preserved archived Guthrie cards for California study participants. GMV was supported by CAPES no. BEX2663/07-4, Brazil. JLW and MK were supported by NIHCA89032 and the Children with Leukaemia Foundation. JLW is a scholar of the Leukemia and Lymphoma Society of America. The NCCLS is supported by research awards NIEHS ES04705 and ES09137.

Ebner K, Suda M, Watzinger F, Lion T (2005) Molecular detection and quantitative analysis of the entire spectrum of human adenoviruses by a two-reaction real-time PCR assay. J Clin Microbiol 43: 3049-3053

Endter C, Dobner T (2004) Cell transformation by human adenoviruses. Curr Top Microbiol Immunol 273: 163-214

Garnett CT, Erdman D, Xu W, Gooding LR (2002) Prevalence and quantitation of species $\mathrm{C}$ adenovirus DNA in human mucosal lymphocytes. J Virol 76: 10608 - 10616

Greaves M (2006) Infection, immune responses and the aetiology of childhood leukaemia. Nat Rev Cancer 6: 193-203

Greaves M (1999) Molecular genetics, natural history and the demise of childhood leukaemia. Eur J Cancer 35: 1941 - 1953

Greaves MF (1988) Speculations on the cause of childhood acute lymphoblastic leukemia. Leukemia 2: 120-125

Greaves MF, Maia AT, Wiemels JL, Ford AM (2003) Leukemia in twins: lessons in natural history. Blood 102: 2321-2333 
Gustafsson B, Huang W, Bogdanovic G, Gauffin F, Nordgren A, Talekar G Ornelles DA, Gooding LR (2007) Adenovirus DNA is detected at increased frequency in Guthrie cards from children who develop acute lymphoblastic leukaemia. Br J Cancer 97: 992 - 994

Gustafsson B, Jernberg AG, Priftakis P, Bogdanovic G (2006) No CMV DNA in Guthrie cards from children who later developed ALL. Pediatr Hematol Oncol 23: 199-205

Hansen HM, Wiemels JL, Wrensch M, Wiencke JK (2007) DNA quantification of whole genome amplified samples for genotyping on a multiplexed bead array platform. Cancer Epidemiol Biomarkers Prev 16: 1686-1690

Isa A, Priftakis P, Broliden K, Gustafsson B (2004) Human parvovirus B19 DNA is not detected in Guthrie cards from children who have developed acute lymphoblastic leukemia. Pediatr Blood Cancer 42: 357-360

Kinlen L (1988) Evidence for an infective cause of childhood leukaemia: comparison of a Scottish new town with nuclear reprocessing sites in Britain. Lancet 2: $1323-1327$

Kosulin K, Haberler C, Hainfellner JA, Amann G, Lang S, Lion T (2007) Investigation of adenovirus occurrence in pediatric tumor entities. J Virol 81: $7629-7635$

MacKenzie J, Gallagher A, Clayton RA, Perry J, Eden OB, Ford AM, Greaves MF, Jarrett RF (2001) Screening for herpesvirus genomes in common acute lymphoblastic leukemia. Leukemia 15: 415-421

MacKenzie J, Greaves MF, Eden TO, Clayton RA, Perry J, Wilson KS, Jarrett RF (2006) The putative role of transforming viruses in childhood acute lymphoblastic leukemia. Haematologica 91: 240-243

Mori H, Colman SM, Xiao Z, Ford AM, Healy LE, Donaldson C, Hows JM, Navarrete C, Greaves M (2002) Chromosome translocations and covert leukemic clones are generated during normal fetal development. Proc Natl Acad Sci USA 99: 8242-8247

Nevels M, Tauber B, Spruss T, Wolf H, Dobner T (2001) 'Hit-and-run' transformation by adenovirus oncogenes. J Virol 75: 3089-3094

Ostlund MR, Wirgart BZ, Linde A, Grillner L (2004) Respiratory virus infections in Stockholm during seven seasons: a retrospective study of laboratory diagnosis. Scand J Infect Dis 36: 460-465

Priftakis P, Dalianis T, Carstensen J, Samuelsson U, Lewensohn-Fuchs I, Bogdanovic G, Winiarski J, Gustafsson B (2003) Human polyomavirus DNA is not detected in Guthrie cards (dried blood spots) from children who developed acute lymphoblastic leukemia. Med Pediatr Oncol 40: 219-223

Smith M (1997) Considerations on a possible viral etiology for B-precursor acute lymphoblastic leukemia of childhood. J Immunother 20: $89-100$

Smith MA, Chen T, Simon R (1997) Age-specific incidence of acute lymphoblastic leukemia in US children: in utero initiation model. $J$ Natl Cancer Inst 89: 1542 - 1544

Van den Veyver IB, Ni J, Bowles N, Carpenter Jr RJ, Weiner CP, Yankowitz J, Moise Jr KJ, Henderson J, Towbin JA (1998) Detection of intrauterine viral infection using the polymerase chain reaction. Mol Genet Metab 63: $85-95$

Wadell G (1984) Molecular epidemiology of human adenoviruses. Curr Top Microbiol Immunol 110: 191 - 220

Wiemels JL, Cazzaniga G, Daniotti M, Eden OB, Addison GM, Masera G, Saha V, Biondi A, Greaves MF (1999) Prenatal origin of acute lymphoblastic leukaemia in children. Lancet 354: 1499-1503 